\title{
Genomic Aberrations Associated with the Pathophysiological Mechanisms of Neurodevelopmental Disorders
}

\author{
Toshiyuki Yamamoto
}

check for updates

Citation: Yamamoto, T. Genomic Aberrations Associated with the Pathophysiological Mechanisms of Neurodevelopmental Disorders. Cells 2021, 10, 2317. https://doi.org/ $10.3390 /$ cells10092317

Academic Editors: Koh-ichi Nagata and Orly Reiner

Received: 26 July 2021

Accepted: 3 September 2021

Published: 4 September 2021

Publisher's Note: MDPI stays neutral with regard to jurisdictional claims in published maps and institutional affiliations.

Copyright: (C) 2021 by the author. Licensee MDPI, Basel, Switzerland. This article is an open access article distributed under the terms and conditions of the Creative Commons Attribution (CC BY) license (https:/ / creativecommons.org/licenses/by/ $4.0 /)$.
Institute of Medical Genetics, Tokyo Women's Medical University, Tokyo 162-8666, Japan; yamamoto.toshiyuki@twmu.ac.jp

\begin{abstract}
Genomic studies are increasingly revealing that neurodevelopmental disorders are caused by underlying genomic alterations. Chromosomal microarray testing has been used to reliably detect minute changes in genomic copy numbers. The genes located in the aberrated regions identified in patients with neurodevelopmental disorders may be associated with the phenotypic features. In such cases, haploinsufficiency is considered to be the mechanism, when the deletion of a gene is related to neurodevelopmental delay. The loss-of-function mutation in such genes may be evaluated using next-generation sequencing. On the other hand, the patients with increased copy numbers of the genes may exhibit different clinical symptoms compared to those with loss-of-function mutation in the genes. In such cases, the additional copies of the genes are considered to have a dominant negative effect, inducing cell stress. In other cases, not the copy number changes, but mutations of the genes are responsible for causing the clinical symptoms. This can be explained by the dominant negative effects of the gene mutations. Currently, the diagnostic yield of genomic alterations using comprehensive analysis is less than $50 \%$, indicating the existence of more subtle alterations or genomic changes in the untranslated regions. Copy-neutral inversions and insertions may be related. Hence, better analytical algorithms specialized for the detection of such alterations are required for higher diagnostic yields.
\end{abstract}

Keywords: nonallelic homologous recombination (NAHR); contiguous gene deletion syndrome; classical microdeletion syndrome; genome disease; diagnostic yield; exome sequencing

\section{Introduction}

Neurodevelopmental disorders are defined as a concept that includes a wide range of symptoms such as intellectual disability, developmental retardation, communication disorders, autism spectrum disorders, attention deficit hyperactivity disorder, learning disabilities, and motor disorders such as tics [1,2]. Cerebral palsy, epilepsy, and psychiatric disorders are also understood as peripheral diseases with the same origin. In other words, it is easy to think of the pathophysiology of many of these symptoms if we consider that some disorder of the synaptic function of the central nervous system causes various combinations of symptoms as clinical symptoms [3].

Since the completion of the Human Genome Project in 2003 (Gibbs), comprehensive genome analysis technology using the primary sequence information of the human genome has advanced, and comprehensive genome copy number analysis using microarrays and comprehensive genome analysis using next-generation sequencers have become possible. Genomic medicine using these analysis techniques has revealed the causes of neurodevelopmental disorders in children one after another [4,5]. Although the diagnostic yields in the chromosome $\mathrm{G}$ banding method was approximately $4 \%$, which was the only comprehensive analysis method before the Human Genome Project, now, the diagnostic rate has increased to about 30-40\% [6]. Because the genomic research of neurodevelopmental disorders is still ongoing, the involvement of the genomic alteration in neurodevelopmental disorders is not yet fully understood. 
Here, the genetic factors of neurodevelopmental disorders and the current state of diagnosis by genomic medicine are outlined.

\section{Chromosomal Deletions}

Genomic copy number variations often contribute to neurodevelopmental disorders, indicating that many genes important for neurogenesis are copy-number-dependent. In general, 22q11.2 microdeletion (MIM \#192430) is the most frequently observed genomic alteration, occurring in one in three-thousand live births [7]. The 22q11.2 microdeletion is caused by nonallelic homologous recombination (NAHR) facilitated by the low-copy repeats (LCRs) present at both ends of the deletions (Figure 1). Similar to the 22q11.2 microdeletion, several other microdeletions are mediated by the LCRs (Table 1). Due to these characteristics of the genome, microdeletion syndromes resulting from the adjacent LCRs are sometimes called "genome diseases". Furthermore, the microdeletion syndromes, identified before the Human Genome Project, are characterized by prominent phenotypic features and are relatively easy to diagnose [8]. Therefore, these are called "classical microdeletion syndromes".

For instance, patients with 22q11.2 microdeletion syndrome often present with tetralogy of Fallot, as a congenital heart disease (Table 1). Additionally, patients with WilliamsBeuren syndrome (MIM \#194050) and Smith-Magenis syndrome (MIM \#182290) also present with congenital heart diseases associated with supraclavicular stenosis and ventricular septal defect, respectively. In addition to congenital heart diseases, patients with these syndromes exhibit distinctive features, which provide important clues for clinical diagnosis. Furthermore, the variable phenotypes in these disease groups are caused by the deletion of multiple adjacent genes, leading to the term "continuous gene deletion syndrome".

"Classical microdeletion syndromes" or "genome diseases" are often associated with various levels of neurodevelopmental abnormalities, because the deleted region contains genes related to neurodevelopment, which are copy-number-dependent. Furthermore, a condition where heterozygous deletions or loss of homologous alleles occur and the remaining functional copy of the gene is incapable of producing a sufficient gene product required for maintaining the normal function is referred to as haploinsufficiency. Haploinsufficiency of genes related to neurodevelopment is an essential mechanism in classical microdeletion syndromes.

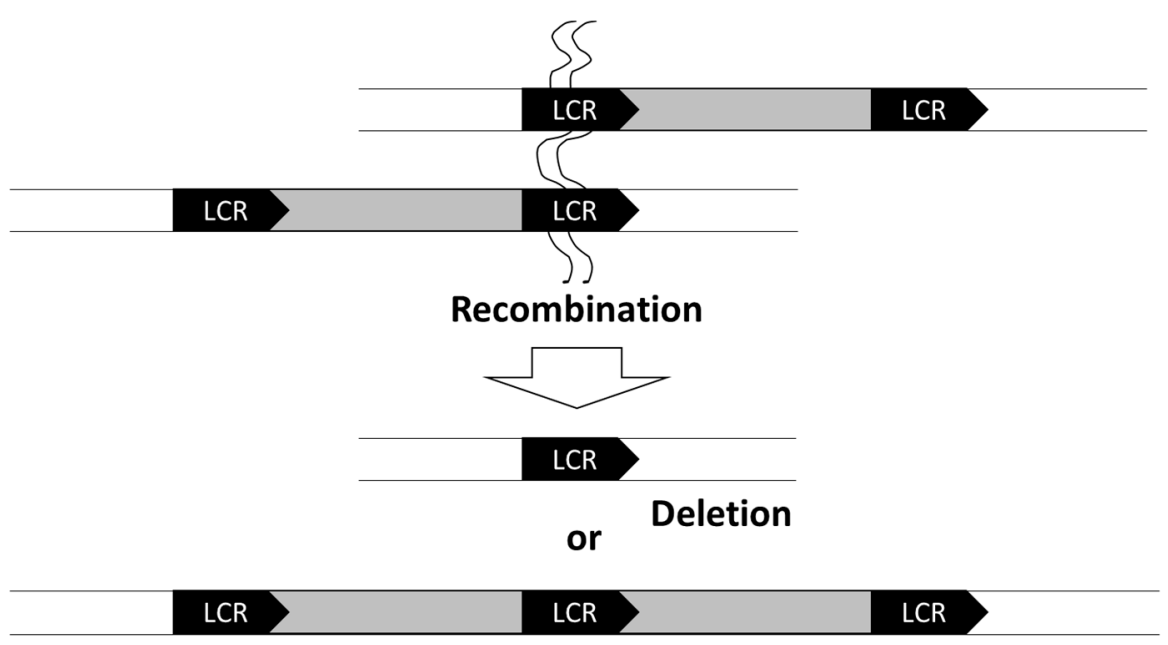

Duplication

Figure 1. Schematic representation of the mechanism of nonallelic homologous recombination. Deletions and duplications of the regions of interest (grey rectangles) can be caused by nonallelic homologous recombination triggered by the presence of low-copy repeats (LCRs). 
Table 1. Classical microdeletion syndromes and reciprocal duplications.

\begin{tabular}{|c|c|c|c|c|}
\hline \multirow{2}{*}{$\begin{array}{l}\text { Chromosomal } \\
\text { Regions }\end{array}$} & \multicolumn{2}{|r|}{ Deletions } & \multicolumn{2}{|c|}{ Duplications } \\
\hline & $\begin{array}{l}\text { Microdeletion } \\
\text { Syndromes }\end{array}$ & Main Clinical Features & $\begin{array}{l}\text { Microduplication } \\
\text { Syndromes }\end{array}$ & Main Clinical Features \\
\hline $22 q 11.2$ & $\begin{array}{l}\text { 22q11.2 deletion } \\
\text { syndrome }\end{array}$ & $\begin{array}{l}\text { Tetralogy of Fallot, language } \\
\text { delay, distinctive facial features }\end{array}$ & $\begin{array}{l}\text { 22q11.2 duplication } \\
\text { syndrome }\end{array}$ & ADHD \\
\hline $7 q 11.23$ & $\begin{array}{l}\text { Williams-Beuren } \\
\text { syndrome }\end{array}$ & $\begin{array}{l}\text { Supraventricular stenosis, } \\
\text { intellectual disability, distinctive } \\
\text { facial features }\end{array}$ & $\begin{array}{l}\text { 7q11.23 duplication } \\
\text { syndrome }\end{array}$ & $\begin{array}{l}\text { Speech delay and autism } \\
\text { spectrum behaviors }\end{array}$ \\
\hline \multirow[t]{2}{*}{$15 q 11$} & $\begin{array}{l}\text { Prader-Willi } \\
\text { syndrome }\end{array}$ & $\begin{array}{l}\text { Developmental delay, hypotonia, } \\
\text { obesity }\end{array}$ & 15q11 duplication & $\begin{array}{l}\text { Intellectual disability, } \\
\text { autism spectrum behaviors }\end{array}$ \\
\hline & $\begin{array}{l}\text { Angelman } \\
\text { syndrome }\end{array}$ & $\begin{array}{l}\text { Developmental delay, epilepsy, } \\
\text { distinctive facial features }\end{array}$ & & \\
\hline $17 \mathrm{p} 11$ & $\begin{array}{l}\text { Smith-Magenis } \\
\text { syndrome }\end{array}$ & $\begin{array}{l}\text { Congenital heart defects, } \\
\text { developmental delay, distinctive } \\
\text { facial features }\end{array}$ & $\begin{array}{l}\text { Potocki-Lupski } \\
\text { syndrome }\end{array}$ & $\begin{array}{l}\text { Intellectual disability, } \\
\text { autism spectrum behaviors }\end{array}$ \\
\hline $5 q 35$ & Sotos syndrome & $\begin{array}{l}\text { Developmental delay, } \\
\text { macrocephaly }\end{array}$ & 5q35 duplication & \\
\hline
\end{tabular}

\section{Microduplications}

The genes that cause neurodevelopmental delay upon their deletion are often copynumber-dependent. These genes affect the neurodevelopmental process, not only by deletions, but also by duplications, (e.g., reciprocally increased number of gene copies, such as in chromosomal partial trisomy). In fact, it is known that neurodevelopmental disorders, such as autism and attention deficit hyperactivity disorder, occur when the regions responsible for classical chromosomal microdeletion syndrome are duplicated (Table 1). Smith-Magenis syndrome is caused by the deletion of the 17p11 region [9], whereas, reciprocal duplication of this region causes Potocki-Lupski syndrome (MIM \#610883), and the patients present with relatively severe developmental disorders [10]. The RAI1 gene, located on $17 \mathrm{p} 11$, is considered to be responsible for the neurodevelopmental disability in both Smith-Magenis and Potocki-Lupski syndromes [11]. In addition, developmental disorders occur when the regions responsible for 22q11.2 microdeletion and Williams syndromes are duplicated.

\section{Different Symptoms Are Associated with Deletion and Duplication of Certain Genes}

Several genes are known to show different clinical symptoms depending on their deletion or duplication (Table 2). For instance, deletion of PMP22 (located on 17p12) causes hereditary neuropathy with susceptibility to pressure palsies (MIM \#162500) [12], while its duplication causes Charcot-Marie-Tooth disease (MIM \#118220) [13]. Similarly, deletion of PLP1 (located on Xq22.2) causes spastic paraplegia associated with peripheral neuropathy; however, its duplication causes a congenital white matter abnormality, known as PelizaeusMerzbacher disease (MIM \#312080) [14,15]. These differences can be attributed to different mechanisms associated with gene deletion or duplication events [16]. Additionally, it is believed that duplication events result in the increased expression of genes, inducing cell stress. 
Table 2. The genes with different phenotypes in deletions and duplications.

\begin{tabular}{cll}
\hline & Deletion & Duplication \\
\hline \multirow{2}{*}{ PMP22 } & $\begin{array}{l}\text { hereditary neuropathy with susceptibility } \\
\text { to pressure palsies (HNPP) }\end{array}$ & Charcot-Marie-Tooth disease \\
\hline PLP1 & spastic paraplegia & Pelizaeus-Merzbacher disease \\
\hline MECP2 & Rett syndrome in female & MECP2 duplication syndrome in male \\
\hline
\end{tabular}

Furthermore, mutation of $M E C P 2$ gene (located on Xq28) causes Rett syndrome (MIM \#312750), a neurodevelopmental disorder specific to females; however, its duplication (MIM \#300815) is asymptomatic in women, while causing severe intellectual disability, epilepsy, and susceptibility to infection in males [17]. The exact mechanism underlying $M E C P 2$ deletion or duplication is unclear to date [18].

\section{Significance of Microarray in Detecting Chromosomal Aberrations}

Since 2010, chromosomal microarray testing has been commonly used for detecting chromosomal aberrations, and it has helped in the diagnosis of several previously unknown chromosomal microdeletion syndromes [19,20]. Among these, a few are novel genomic diseases that are caused by LCR-mediated NAHR; one such disease is $16 \mathrm{p} 11.2 \mathrm{mi}-$ crodeletion syndrome (MIM \#611913) [21]. The 16p11.2 microdeletion is relatively frequent and is observed in approximately $1 / 100$ patients with autism. Furthermore, deletion or duplication of 16p11.2 causes similar developmental disorders, and their clinical diagnosis is difficult, contrary to the classical microdeletion syndromes, as the patients have very few differentiating symptoms. Hence, comprehensive copy number variation (CNV) analysis by microarray is the only diagnostic method for 16p11.2 microdeletion syndrome.

The chromosomal microdeletions caused by LCR-mediated NAHR are limited, and various chromosomal aberrations detected by microarray are caused by random breakpoints (Table 3). However, even if the breakpoints are not common, the chromosomal microdeletions that can be clinically classified as the same entities due to the common clinical symptoms include the main gene(s) in the deleted region (Figure 2). Thus, the clinical symptoms can be diagnosed because of the involvement of the main gene(s) in the deleted regions.

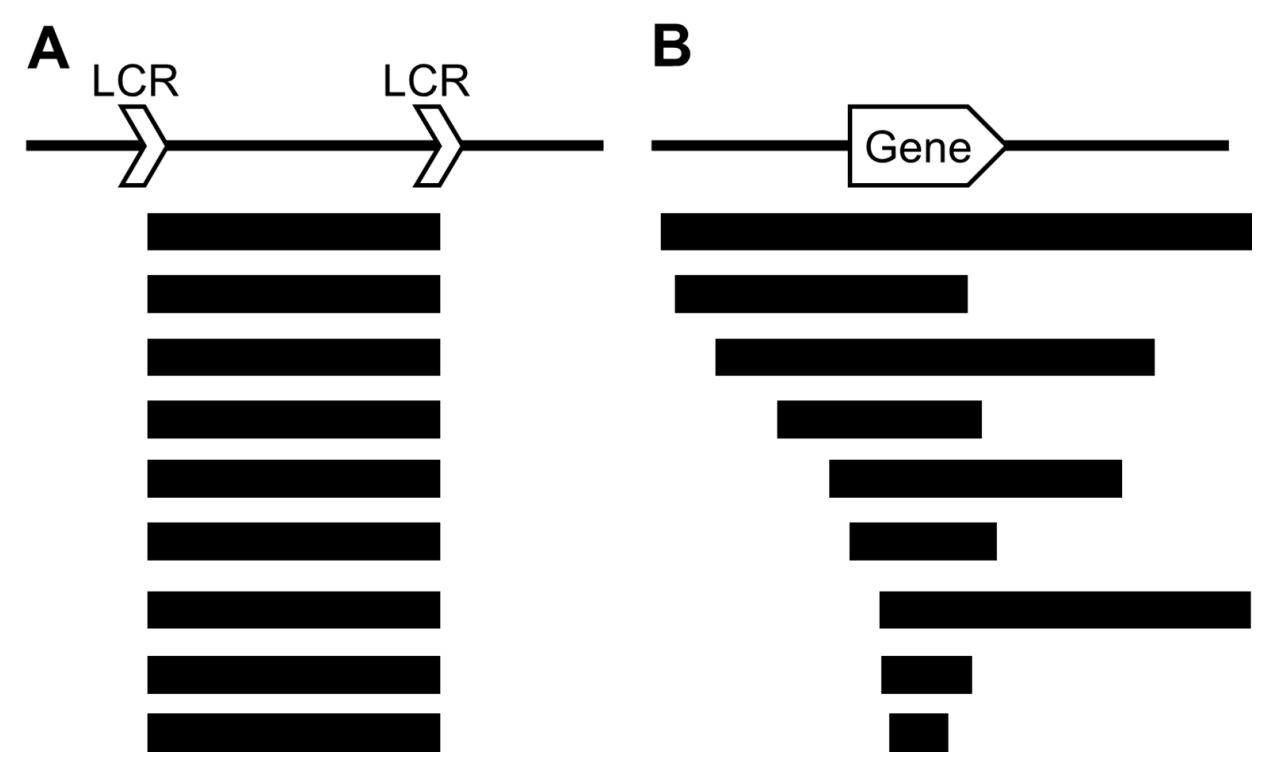

Figure 2. Schematic representation of the patterns of deletions. (A) Deletions (black rectangles) caused by nonallelic homologous recombination triggered by surrounding LCRs show the same breakpoints in patients. (B) Deletions (black rectangles) with random breakpoints, however, include specific gene(s). 
Table 3. Chromosomal regions and phenotypes.

\begin{tabular}{|c|c|c|}
\hline Regions & Responsible Gene(s) & Phenotypes \\
\hline \multicolumn{3}{|l|}{$\begin{array}{l}\text { Microdeletions/duplications } \\
\text { derived from NAHR }\end{array}$} \\
\hline 1q21.1 deletion/duplication & & Developmental delay, distinctive features, congenital anomalies \\
\hline $3 q 29$ deletion & DLG1, PAK2 & Developmental delay, psychiatric symptoms \\
\hline $15 q 13.3$ deletion & CHRNA7 & Intellectual disability, epilepsy \\
\hline 16p11.2 deletion/duplication & & Developmental disorder \\
\hline 17q12 deletion/duplication & $H N F 1 B$ & Maturity onset diabetes of the young (MODY) \\
\hline 17q21.31 deletion/duplication & CRHR1, MAPT & Developmental delay, muscular hypotonia, distinctive features \\
\hline \multicolumn{3}{|l|}{$\begin{array}{l}\text { Microdeletions/duplications } \\
\text { derived from random breakpoints }\end{array}$} \\
\hline 1q32 deletion & IRF6 & Van der Woude syndrome \\
\hline $1 q 41 q 42$ deletion & DISP1 & Developmental delay, epilepsy, distinctive features \\
\hline 2p15-p16.1 deletion & & Autism spectrum disorder \\
\hline 2q23.1 deletion & MBD5 & Severe developmental delay, epilepsy, microcephaly \\
\hline 2q33 deletion/duplication & SATB2 & Intellectual disability \\
\hline 3p21.31 deletion & $B S N$ & Developmental delay, white matter abnormality, hyperCKemia \\
\hline $3 q 13.31$ deletion & ZBTB20 & Language delay \\
\hline $5 q 14$ deletion & $M E F 2 C$ & Severe developmental delay, epilepsy, brain abnormalities \\
\hline 5q31.3deletion & PURA, NRG2 & Severe developmental delay, epilepsy \\
\hline $8 \mathrm{q} 24$ deletion & EXT1, TRPS1 & Langer-Giedion syndrome \\
\hline 9q22.3 deletion & PTCH1 & Gorlin syndrome \\
\hline 10q22 deletion & KAT6B & Ohdo syndrome \\
\hline 10q23 deletion & PTEN & Juvenile polyposis \\
\hline 11p13 deletion & WT1, PAX6 & WAGR syndrome \\
\hline 11p11.2 deletion & $E X T 2, A L X 4$ & Potocki-Shaffer syndrome \\
\hline 12q24.21 deletion & MED13L & Intellectual disability \\
\hline 13q32 deletion & ZIC2 & Holoprosencephaly \\
\hline $15 q 22.2$ deletion & NRG2, RORA & Developmental delay, epilepsy \\
\hline 16q24.3 deletion & ANKRD11, ZNF778 & Autism spectrum disorder \\
\hline 17p13.1 deletion & $D L G 4, G A B A R A P$ & Intellectual disability, epilepsy \\
\hline 18q12.3 deletion & SETBP1 & Language delay \\
\hline 18q21.2 deletion & TCF4 & Pitt-Hopkins syndrome \\
\hline 19p13.2 deletion & NFIX & Malan syndrome \\
\hline Xp22.3 deletion & KAL1 & Kallmann syndrome \\
\hline Xp21-22 deletion & $C D K L 5, A R X$ & Epileptic encephalopathy \\
\hline Xp11.4 deletion & CASK & Developmental delay, microcephaly \\
\hline Xp11.22 deletion & HUWE1 & Developmental delay \\
\hline Xq11.1 deletion & ARHGEF9 & Developmental delay, epilepsy \\
\hline Xq28 duplication & MECP2 & Developmental delay, epilepsy \\
\hline
\end{tabular}




\section{Genes Identified Based on Their Genomic Copy Number Changes}

In 2011, we identified a small deletion in Xq11.1, in a patient with epileptic encephalopathy [22]. The deleted region contained the ARHGEF9 gene. Additionally, we identified a nonsense mutation in ARHGEF9 in a different patient with epileptic encephalopathy. Based on these findings, ARHGEF9 has been registered as the causative gene for developmental and epileptic encephalopathy 8 (MIM \#300607) [23].

Further, in 2011, we reported two cases of 5q31 microdeletion for the first time [24]. Both patients exhibited common clinical symptoms with infantile epileptic encephalopathy and shared severe psychomotor development. Following our study, two other studies reporting overlapping chromosomal microdeletions narrowed down the candidate gene responsible for the syndrome to be PURA $[25,26]$. Finally, next-generation sequencing (NGS) of patients with severe psychomotor development and infantile epileptic encephalopathy revealed a large number of de novo mutations in PURA, confirming the association of PURA with 5q31 microdeletion syndrome [27]. Hence, currently, 5q31 microdeletion syndrome is known as a PURA-related neurodevelopmental disorder.

In another study, we found a 15q14 microdeletion in a patient with mild neurodevelopmental disorder with ventricular septal defect and submucosal cleft palate [28]. Further, the deleted region contained MEIS2, which has since been identified as the causative gene for neurodevelopmental disorders associated with cleft palate and congenital heart disease [29].

Hence, as discussed above, when the phenotype caused by chromosomal deletion and gene mutation is the same, it is considered to be caused by haploinsufficiency and is relatively easy to understand.

\section{Genes Whose Phenotypes Are Not Affected by Genomic Copy Number Changes}

ZBTB20, located at 3q13.31, has been identified as the causative gene for Primrose syndrome (MIM \#259050), which is associated with severe neurodevelopmental disorders [30]. Previously, we found that the symptoms associated with neurodevelopmental disorders were very mild and inconsistent in the cases with $3 q 13$ deletion compared to those observed in Primrose syndrome [31]. Therefore, Primrose syndrome is unlikely to be caused by haploinsufficiency of ZBTB20 and is thought to be the result of the dominant negative effect of $Z B T B 20$ mutations.

SATB2 is located at $2 \mathrm{q} 33.1$ and is known as the causative gene for Glass syndrome (MIM \#612313), which causes characteristic symptoms, such as intellectual disability and dentition malformation. Patients with $S A T B 2$ mutations and deletions show similar symptoms [32,33]. Furthermore, HECW2 is located on the 3-Mb centromeric side of SATB2 at 2 q32.3-q33.1 and has recently been identified as a causative gene for neurodevelopmental disorders with hypotonia, seizures, and absent language (NDHSAL; MIM \#617268) $[34,35]$. However, microdeletion of 2q32.3-q33.1 is not known to cause severe developmental disorders. Hence, the neurodevelopmental disorders due to HECW2 mutations are considered to be because of the dominant negative effect [36].

Thus, the pathomechanism of neurodevelopmental disorders can be revealed by understanding whether the gene mutation is due to haploinsufficiency or the dominant negative effect. Therefore, it is important to compare the phenotypes of patients due to gene deletions and the gene mutations associated with the dominant negative effects.

\section{Diagnostic Yield of the Methods Used for Genetic Testing}

The diagnostic yield of chromosomal microarray testing has been found to be $12-20 \%[20,37,38]$. Furthermore, the diagnostic yield does not vary depending on the type of platform used, such as comparative genomic hybridization or single-nucleotide polymorphism, indicating that it does not depend on the resolution of the microarrays.

When there are no pathogenic CNVs, single-nucleotide variants (SNVs) may be associated with the occurrence of the diseases. Currently, NGS-based exome sequencing is recommended to detect SNVs [1]. The diagnostic yield of exome sequencing is approxi- 
mately $30 \%$ [6]. Thus, more than $40 \%$ of the cases can be diagnosed using either genome copy number analysis or exome sequencing. However, for the remaining patients (more than $50 \%$ ), the genomic background of the diseases remains unclear (Figure 3).

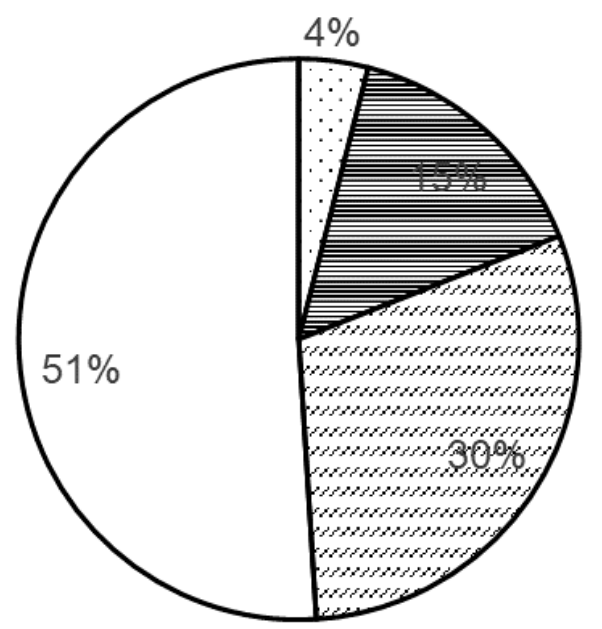

口Conventional karyotyping

日Chromosomal microarray testing

DExome sequencing

口Undiagnosed

Figure 3. Schematic representation of diagnostic yields of various methods used for genetic testing. Diagnostic yields of the methods are shown in \% plot format.

\section{Undetected Genomic Backgrounds}

What are the causes of the diseases where no pathogenic CNVs or SNVs have been observed? One possible cause in such cases is the genomic copy number aberrations; however, they are very small such that cannot be detected by microarray with the general resolution. For instance, most patients with Duchenne muscular dystrophy (DMD; MIM \#310200, 71\%) show exonic deletions in the DMD gene, and only $17 \%$ of the patients show pathogenic SNVs [39]. As this is a well-known phenomenon, multiplex ligation probe amplification is primarily used for the diagnosis of $D M D$. Previously, we identified an exonic deletion in $M E D 13 L$. The microarray results showed an aberrant log2 ratio in only three probes; hence, we used a different method to confirm the deletion [40]. Thus, such small CNVs could be misdiagnosed by microarray and exome sequencing.

The other possible mechanisms are silent mutations, deep intronic variants, aberrations in the noncoding regions, and genomic methylation. A few silent mutations and deep intronic variants are known to affect the splicing machinery [41-43]. As these variants are generally excluded during the filtering of exome sequencing data, those affecting the splicing machinery may have been overlooked. Furthermore, aberrations in the noncoding regions cannot be detected by exome sequencing, and scientific evidence of their association with disease occurrence is insufficient. Additionally, altered methylation of the wild-type sequences is known to be the underlying cause of a few diseases. However, methylation abnormalities cannot be detected by microarray and exome sequencing.

However, even if such abnormalities are detected, it may be difficult to confirm their association with the diseases. For instance, the precise detection of small CNVs is not possible. However, while targeting small CNVs, a large number of nonpathogenic CNVs may be detected, making it difficult to distinguish the pathogenic CNVs. A similar problem may arise with other discussed mechanisms. Exome sequencing covers only approximately $2 \%$ of the entire genome. However, sequencing the entire genome may result in a large number of variants, making the visual filtering difficult. Thus, analyzing the entire genome is not practical unless a more accurate database is developed and automated filtering using artificial intelligence is introduced. 


\section{Novel Developments Expected in Whole Genome Analysis for the Detection of Chromosomal Aberrations}

To date, we have analyzed CNVs in many patients. Among the analyzed cases, a few have exhibited comparatively more complicated structural abnormalities, such as three consecutive deletions and additional triplications in the duplicated fragment [44,45]. Further, we performed whole-genome analysis to clarify the patterns of structural abnormalities [46]. The results suggested that seemingly simple structural abnormalities may be caused by more complex changes, such as inversions and insertions.

Thus, there is a possibility that the copy-neutral rearrangements, such as inversions or insertions, contribute to disease occurrence. However, they cannot be detected through microarray (Figure 4), as evidenced in the literature [47-49]. Hence, with the usage of whole-genome analysis and the availability of appropriate algorithms or analysis software that can efficiently detect inversions and insertions without copy number changes, the diagnostic yields of the disease-causing genomic backgrounds will increase.

\section{Wild-type sequence}
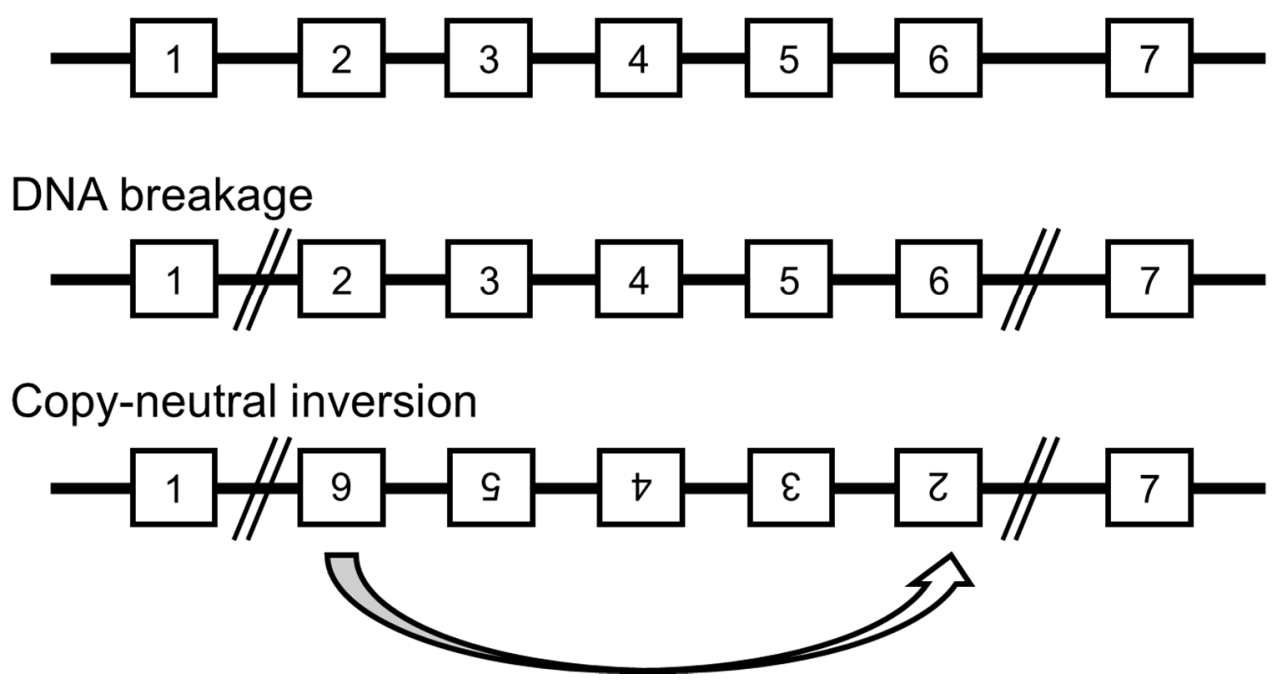

Figure 4. Possible mechanism of copy-neutral inversion that cannot be detected by chromosomal microarray testing and exome sequencing.

\section{Conclusions}

The involvement of genomic alterations in neurodevelopmental disorders and the progress of their analysis technology were outlined. Chromosomal microarray testing is positioned as the first-tier testing for undiagnosed neurodevelopmental disorders [20]. In approximately $15 \%$ of patients, pathogenic CNVs are expected to be detected, and the final diagnosis would be obtained. If the diagnosis cannot be obtained by the chromosomal microarray testing, SNVs are recommended to be comprehensively analyzed by exome analysis. Exome analysis will reveal pathogenic SNVs in approximately $30 \%$ of patients. If neither microarray chromosomal testing nor exome analysis show pathogenic variants, there may be variants that cannot be detected by these techniques. Exonic deletions/duplications, copy-neutral inversions/insertions, and variants in noncoding regions would have been underdiagnosed. Therefore, it is expected that whole-genome analysis will detect such alterations that have not been found so far and that the diagnostic yield will be further improved (Figure 5). The genomic basis of neurodevelopmental disorders has not yet been fully elucidated, and genomic testing methods will be refined further in the future. 


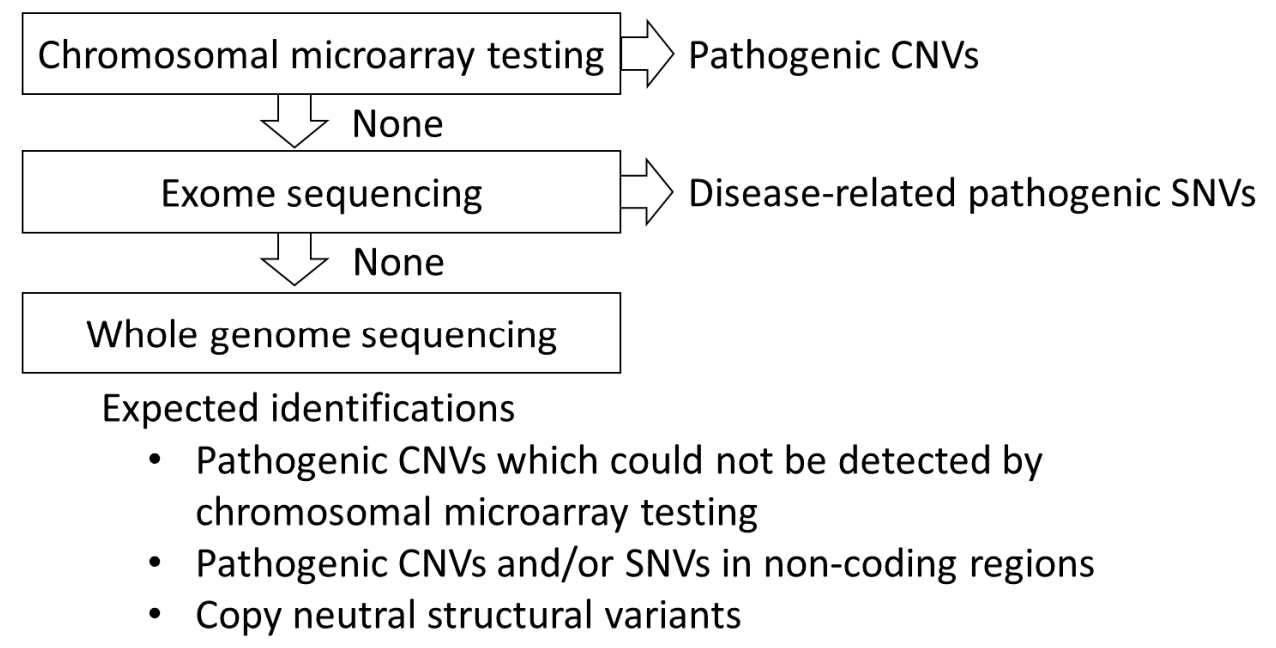

Figure 5. Schematic representation of the stepwise diagnosis for patients with neurodevelopmental disorder.

Funding: This research was funded by JSPS KAKENHI JP18K07803.

Institutional Review Board Statement: The study was conducted according to the guidelines of the Declaration of Helsinki and approved by the Institutional Review Board of Tokyo Women's Medical University.

Informed Consent Statement: Not applicable.

Data Availability Statement: Not applicable.

Conflicts of Interest: The author declares no conflict of interest.

\section{References}

1. Savatt, J.M.; Myers, S.M. Genetic Testing in Neurodevelopmental Disorders. Front. Pediatr. 2021, 9, 526779. [CrossRef]

2. Blesson, A.; Cohen, J.S. Genetic Counseling in Neurodevelopmental Disorders. Cold Spring Harb. Perspect. Med. 2020, 10, a036533. [CrossRef]

3. Henstridge, C.M.; Pickett, E.; Spires-Jones, T.L. Synaptic pathology: A shared mechanism in neurological disease. Ageing Res. Rev. 2016, 28, 72-84. [CrossRef]

4. Deciphering Developmental Disorders Study. Prevalence and architecture of de novo mutations in developmental disorders. Nature 2017, 542, 433-438. [CrossRef] [PubMed]

5. Moyses-Oliveira, M.; Yadav, R.; Erdin, S.; Talkowski, M.E. New gene discoveries highlight functional convergence in autism and related neurodevelopmental disorders. Curr. Opin. Genet. Dev. 2020, 65, 195-206. [CrossRef]

6. Yamamoto, T.; Imaizumi, T.; Yamamoto-Shimojima, K.; Lu, Y.; Yanagishita, T.; Shimada, S.; Chong, P.F.; Kira, R.; Ueda, R.; Ishiyama, A.; et al. Genomic backgrounds of Japanese patients with undiagnosed neurodevelopmental disorders. Brain Dev. 2019, 41, 776-782. [CrossRef] [PubMed]

7. Emanuel, B.S. Molecular mechanisms and diagnosis of chromosome 22q11.2 rearrangements. Dev. Disabil. Res. Rev. 2008, 14, 11-18. [CrossRef]

8. Gibbs, R.A. The Human Genome Project changed everything. Nat. Rev. Genet. 2020, 21, 575-576. [CrossRef]

9. Rive Le Gouard, N.; Jacquinet, A.; Ruaud, L.; Deleersnyder, H.; Ageorges, F.; Gallard, J.; Lacombe, D.; Odent, S.; Mikaty, M.; Manouvrier-Hanu, S.; et al. Smith-Magenis syndrome: Clinical and behavioral characteristics in a large retrospective cohort. Clin. Genet. 2021, 99, 519-528. [CrossRef] [PubMed]

10. Ciaccio, C.; Pantaleoni, C.; Milani, D.; Alfei, E.; Sciacca, F.L.; Canafoglia, L.; Erbetta, A.; D'Arrigo, S. Neurological phenotype of Potocki-Lupski syndrome. Am. J. Med. Genet. A 2020, 182, 2317-2324. [CrossRef]

11. Garay, P.M.; Chen, A.; Tsukahara, T.; Rodríguez Díaz, J.C.; Kohen, R.; Althaus, J.C.; Wallner, M.A.; Giger, R.J.; Jones, K.S.; Sutton, M.A.; et al. RAI1 Regulates Activity-Dependent Nascent Transcription and Synaptic Scaling. Cell Rep. 2020, 32, 108002. [CrossRef] [PubMed]

12. Pantera, H.; Shy, M.E.; Svaren, J. Regulating PMP22 expression as a dosage sensitive neuropathy gene. Brain Res. 2020, 1726, 146491. [CrossRef]

13. Marinko, J.T.; Carter, B.D.; Sanders, C.R. Direct relationship between increased expression and mistrafficking of the CharcotMarie-Tooth-associated protein PMP22. J. Biol. Chem. 2020, 295, 11963-11970. [CrossRef] [PubMed] 
14. Inoue, K. PLP1-related inherited dysmyelinating disorders: Pelizaeus-Merzbacher disease and spastic paraplegia type 2. Neurogenetics 2005, 6, 1-16. [CrossRef]

15. Inoue, K. Pelizaeus-Merzbacher Disease: Molecular and Cellular Pathologies and Associated Phenotypes. Adv. Exp. Med. Biol. 2019, 1190, 201-216. [CrossRef]

16. Yamamoto, T.; Shimojima, K. Pelizaeus-Merzbacher disease as a chromosomal disorder. Congenit Anom. 2013, 53, 3-8. [CrossRef]

17. Yamamoto, T.; Shimojima, K.; Shimada, S.; Yokochi, K.; Yoshitomi, S.; Yanagihara, K.; Imai, K.; Okamoto, N. Clinical impacts of genomic copy number gains at Xq28. Hum. Genome Var. 2014, 1, 14001. [CrossRef]

18. Vermudez, S.A.D.; Gogliotti, R.G.; Arthur, B.; Buch, A.; Morales, C.; Moxley, Y.; Rajpal, H.; Conn, P.J.; Niswender, C.M. Profiling beneficial and potential adverse effects of $\mathrm{MeCP} 2$ overexpression in a hypomorphic Rett syndrome mouse model. Genes Brain Behav. 2021, e12752. [CrossRef]

19. Battaglia, A.; Doccini, V.; Bernardini, L.; Novelli, A.; Loddo, S.; Capalbo, A.; Filippi, T.; Carey, J.C. Confirmation of chromosomal microarray as a first-tier clinical diagnostic test for individuals with developmental delay, intellectual disability, autism spectrum disorders and dysmorphic features. Eur. J. Paediatr. Neurol. 2013, 17, 589-599. [CrossRef] [PubMed]

20. Miller, D.T.; Adam, M.P.; Aradhya, S.; Biesecker, L.G.; Brothman, A.R.; Carter, N.P.; Church, D.M.; Crolla, J.A.; Eichler, E.E.; Epstein, C.J.; et al. Consensus statement: Chromosomal microarray is a first-tier clinical diagnostic test for individuals with developmental disabilities or congenital anomalies. Am. J. Hum. Genet. 2010, 86, 749-764. [CrossRef]

21. Kumar, R.A.; KaraMohamed, S.; Sudi, J.; Conrad, D.F.; Brune, C.; Badner, J.A.; Gilliam, T.C.; Nowak, N.J.; Cook, E.H., Jr.; Dobyns, W.B.; et al. Recurrent 16p11.2 microdeletions in autism. Hum. Mol. Genet. 2008, 17, 628-638. [CrossRef] [PubMed]

22. Shimojima, K.; Sugawara, M.; Shichiji, M.; Mukaida, S.; Takayama, R.; Imai, K.; Yamamoto, T. Loss-of-function mutation of collybistin is responsible for X-linked mental retardation associated with epilepsy. J. Hum. Genet. 2011, 56, 561-565. [CrossRef]

23. Alber, M.; Kalscheuer, V.M.; Marco, E.; Sherr, E.; Lesca, G.; Till, M.; Gradek, G.; Wiesener, A.; Korenke, C.; Mercier, S.; et al. ARHGEF9 disease: Phenotype clarification and genotype-phenotype correlation. Neurol. Genet. 2017, 3, e148. [CrossRef] [PubMed]

24. Shimojima, K.; Isidor, B.; Le Caignec, C.; Kondo, A.; Sakata, S.; Ohno, K.; Yamamoto, T. A new microdeletion syndrome of 5q31.3 characterized by severe developmental delays, distinctive facial features, and delayed myelination. Am. J. Med. Genet. A 2011, 155, 732-736. [CrossRef]

25. Hosoki, K.; Ohta, T.; Natsume, J.; Imai, S.; Okumura, A.; Matsui, T.; Harada, N.; Bacino, C.A.; Scaglia, F.; Jones, J.Y.; et al. Clinical phenotype and candidate genes for the 5q31.3 microdeletion syndrome. Am. J. Med. Genet. A 2012, 158a, 1891-1896. [CrossRef]

26. Brown, N.; Burgess, T.; Forbes, R.; McGillivray, G.; Kornberg, A.; Mandelstam, S.; Stark, Z. 5q31.3 Microdeletion syndrome: Clinical and molecular characterization of two further cases. Am. J. Med. Genet. A 2013, 161a, 2604-2608. [CrossRef] [PubMed]

27. Lalani, S.R.; Zhang, J.; Schaaf, C.P.; Brown, C.W.; Magoulas, P.; Tsai, A.C.; El-Gharbawy, A.; Wierenga, K.J.; Bartholomew, D.; Fong, C.T.; et al. Mutations in PURA cause profound neonatal hypotonia, seizures, and encephalopathy in 5 q31.3 microdeletion syndrome. Am. J. Hum. Genet. 2014, 95, 579-583. [CrossRef]

28. Shimojima, K.; Ondo, Y.; Okamoto, N.; Yamamoto, T. A 15q14 microdeletion involving MEIS2 identified in a patient with autism spectrum disorder. Hum. Genome Var. 2017, 4, 17029. [CrossRef]

29. Fujita, A.; Isidor, B.; Piloquet, H.; Corre, P.; Okamoto, N.; Nakashima, M.; Tsurusaki, Y.; Saitsu, H.; Miyake, N.; Matsumoto, N. De novo MEIS2 mutation causes syndromic developmental delay with persistent gastro-esophageal reflux. J. Hum. Genet. 2016, 61, 835-838. [CrossRef]

30. Yamamoto-Shimojima, K.; Imaizumi, T.; Akagawa, H.; Kanno, H.; Yamamoto, T. Primrose syndrome associated with unclassified immunodeficiency and a novel ZBTB20 mutation. Am. J. Med. Genet. A 2020, 182, 521-526. [CrossRef]

31. Shimojima, K.; Saito, K.; Yamamoto, T. A de novo 1.9-Mb interstitial deletion of 3q13.2q13.31 in a girl with dysmorphic features, muscle hypotonia, and developmental delay. Am. J. Med. Genet. A 2009, 149a, 1818-1822. [CrossRef]

32. Leoyklang, P.; Suphapeetiporn, K.; Siriwan, P.; Desudchit, T.; Chaowanapanja, P.; Gahl, W.A.; Shotelersuk, V. Heterozygous nonsense mutation SATB2 associated with cleft palate, osteoporosis, and cognitive defects. Hum. Mutat. 2007, 28, 732-738. [CrossRef] [PubMed]

33. Rosenfeld, J.A.; Ballif, B.C.; Lucas, A.; Spence, E.J.; Powell, C.; Aylsworth, A.S.; Torchia, B.A.; Shaffer, L.G. Small deletions of SATB2 cause some of the clinical features of the 2q33.1 microdeletion syndrome. PLoS ONE 2009, 4, e6568. [CrossRef] [PubMed]

34. Berko, E.R.; Cho, M.T.; Eng, C.; Shao, Y.; Sweetser, D.A.; Waxler, J.; Robin, N.H.; Brewer, F.; Donkervoort, S.; Mohassel, P.; et al. De novo missense variants in HECW2 are associated with neurodevelopmental delay and hypotonia. J. Med. Genet. 2017, 54, 84-86. [CrossRef] [PubMed]

35. Halvardson, J.; Zhao, J.J.; Zaghlool, A.; Wentzel, C.; Georgii-Hemming, P.; Månsson, E.; Ederth Sävmarker, H.; Brandberg, G.; Soussi Zander, C.; Thuresson, A.C.; et al. Mutations in HECW2 are associated with intellectual disability and epilepsy. J. Med. Genet. 2016, 53, 697-704. [CrossRef] [PubMed]

36. Yanagishita, T.; Hirade, T.; Shimojima Yamamoto, K.; Funatsuka, M.; Miyamoto, Y.; Maeda, M.; Yanagi, K.; Kaname, T.; Nagata, S.; Nagata, M.; et al. HECW2-related disorder in four Japanese patients. Am. J. Med. Genet. A 2021. [CrossRef]

37. Hochstenbach, R.; van Binsbergen, E.; Engelen, J.; Nieuwint, A.; Polstra, A.; Poddighe, P.; Ruivenkamp, C.; Sikkema-Raddatz, B.; Smeets, D.; Poot, M. Array analysis and karyotyping: Workflow consequences based on a retrospective study of 36,325 patients with idiopathic developmental delay in the Netherlands. Eur. J. Med. Genet. 2009, 52, 161-169. [CrossRef] 
38. Martin, C.L.; Ledbetter, D.H. Chromosomal Microarray Testing for Children With Unexplained Neurodevelopmental Disorders. JAMA 2017, 317, 2545-2546. [CrossRef] [PubMed]

39. Lim, K.R.Q.; Nguyen, Q.; Yokota, T. Genotype-Phenotype Correlations in Duchenne and Becker Muscular Dystrophy Patients from the Canadian Neuromuscular Disease Registry. J. Pers. Med. 2020, 10, 241. [CrossRef]

40. Yamamoto, T.; Shimojima, K.; Ondo, Y.; Shimakawa, S.; Okamoto, N. MED13L haploinsufficiency syndrome: A de novo frameshift and recurrent intragenic deletions due to parental mosaicism. Am. J. Med. Genet. A 2017, 173, 1264-1269. [CrossRef] [PubMed]

41. Dehainault, C.; Michaux, D.; Pagès-Berhouet, S.; Caux-Moncoutier, V.; Doz, F.; Desjardins, L.; Couturier, J.; Parent, P.; StoppaLyonnet, D.; Gauthier-Villars, M.; et al. A deep intronic mutation in the RB1 gene leads to intronic sequence exonisation. Eur. J. Hum. Genet. 2007, 15, 473-477. [CrossRef]

42. Encarnação, M.; Coutinho, M.F.; Cho, S.M.; Cardoso, M.T.; Ribeiro, I.; Chaves, P.; Santos, J.I.; Quelhas, D.; Lacerda, L.; Leão Teles, E.; et al. NPC1 silent variant induces skipping of exon 11 (p.V562V) and unfolded protein response was found in a specific Niemann-Pick type C patient. Mol. Genet. Genom. Med. 2020, 8, e1451. [CrossRef]

43. Sun, Y.; Li, Y.; Chen, M.; Luo, Y.; Qian, Y.; Yang, Y.; Lu, H.; Lou, F.; Dong, M. A Novel Silent Mutation in the L1CAM Gene Causing Fetal Hydrocephalus Detected by Whole-Exome Sequencing. Front. Genet. 2019, 10, 817. [CrossRef] [PubMed]

44. Imaizumi, T.; Yamamoto-Shimojima, K.; Yanagishita, T.; Ondo, Y.; Nishi, E.; Okamoto, N.; Yamamoto, T. Complex chromosomal rearrangements of human chromosome 21 in a patient manifesting clinical features partially overlapped with that of Down syndrome. Hum. Genet. 2020, 139, 1555-1563. [CrossRef]

45. Imaizumi, T.; Yamamoto-Shimojima, K.; Yanagishita, T.; Ondo, Y.; Yamamoto, T. Analyses of breakpoint junctions of complex genomic rearrangements comprising multiple consecutive microdeletions by nanopore sequencing. J. Hum. Genet. 2020, 65, 735-741. [CrossRef] [PubMed]

46. Yanagishita, T.; Imaizumi, T.; Yamamoto-Shimojima, K.; Yano, T.; Okamoto, N.; Nagata, S.; Yamamoto, T. Breakpoint junction analysis for complex genomic rearrangements with the caldera volcano-like pattern. Hum. Mutat. 2020, 41, 2119-2127. [CrossRef] [PubMed]

47. Morak, M.; Steinke-Lange, V.; Massdorf, T.; Benet-Pages, A.; Locher, M.; Laner, A.; Kayser, K.; Aretz, S.; Holinski-Feder, E. Prevalence of CNV-neutral structural genomic rearrangements in MLH1, MSH2, and PMS2 not detectable in routine NGS diagnostics. Fam. Cancer 2020, 19, 161-167. [CrossRef] [PubMed]

48. Rajagopalan, R.; Gilbert, M.A.; McEldrew, D.A.; Nassur, J.A.; Loomes, K.M.; Piccoli, D.A.; Krantz, I.D.; Conlin, L.K.; Spinner, N.B. Genome sequencing increases diagnostic yield in clinically diagnosed Alagille syndrome patients with previously negative test results. Genet. Med. 2021, 23, 323-330. [CrossRef]

49. Weisschuh, N.; Mazzola, P.; Heinrich, T.; Haack, T.; Wissinger, B.; Tonagel, F.; Kelbsch, C. First submicroscopic inversion of the OPA1 gene identified in dominant optic atrophy_A case report. BMC Med. Genet. 2020, 21, 236. [CrossRef] 